\title{
Back To Punjab
}

Amrit "Noyz" Singh

info@noyzhiphop.com

In 2013, I released a song entitled "Back to Punjab" featuring California-based emcee Mandeep Sethi, and produced by Satnam Singh Chatha. The song and the connections between the verses play out like conversations between long-lost relatives writing letters to each other from across the oceans.

In the first verse, Mandeep speaks from the perspective of someone who has migrated from Punjab to the United States. He details the struggles he faces to find work, earn money, and at the same time, to financially support his family still in Punjab. His verse is tinged with regret for leaving. He conveys a sense of helplessness that he can't physically be there to support his loved ones.

When putting together my verse for this song (see "Back To Punjab" below), I decided to write from the opposite perspective. My character is someone who has never left Punjab and is letting his friend in the US know of the injustices that have been taking place during the time they've been apart.

My verse shows how some of the aspects of home that we as Punjabis take pride in language, natural resources, familial ties - have all been harshly impacted by the sociopolitical climate within India and Punjab, over the last few decades, and unfortunately, replaced with drug abuse, state violence, intergenerational trauma, and scarcity of resources.

The verse discusses how the place where one should feel the most free - in their own home - can become a cage. Despite everything this individual encounters, he still closes his verse with a positive outlook. He holds on to hope that things will get better for his home and his people.

\section{Back To Punjab}

My grandfather was massacred in the streets of Delhi, though I've never met him, fam says I've got his features in me flee the city, grandmother worked the widow colony but left and took her daughters to Punjab where the heart in me was made raised with my brothers by a farmer who would slave to save up, but underneath his armor had his heart broken gun smoking from the false encounters they put the dark around us, the cause of the loss of thousands hard to count them when they're dying by their own hands 
and ingesting the pesticides applied on their own land

the Green Revolution, abusive regime

revenue streams from liquor taxes, a future of fiends

got me stuck

my brothers in the same trap, vein tracks

belts wrapped around their arms, needles in a haystack

from heroin to opiates, tearing at the closely knit

and dealing with twice the terror for every bit of hope we get

so I wonder if we're deserving of our fate

when the water gets diverted out of state

and they're calling us insurgents of our faith

got me pondering a certain escape

beyond the temporary tourniquets they've placed

so I hold on, grow strong, now my skin is thicker

Punjab awaits its makers, awake us, and still I'm with you

a picture from my pen to show you it's getting deep

from the five rivers, where all of my ancestors sleep

\section{Link to the Audio Recording}

Back To Panjab (Produced by Satnam Singh Chatha)

https://noyzhiphop.tumblr.com/post/44031413760/back-to-panjab-produced-by-satnam-singh-chatha

Link for the previous version of the written piece:

Back To Panjab (Produced by Satnam Singh Chatha)

Mandeep Sethi \& Noyz

https://noyzhiphop.tumblr.com/post/44031413760/back-to-panjab-produced-by-satnam-singh-chatha 